\title{
Scientists rip US for cutbacks to global AIDS summit
}

In a move that has angered AIDS researchers worldwide, the US government has slashed its contribution to the $15^{\text {th }}$ International AIDS Conference, to be held in July in Bangkok.

The US Department of Health and Human Services (HHS) has limited the number of its employees at the conference to 50, down from 236 at the last meeting in Barcelona in 2002. The measure primarily affects researchers at the US National Institutes of Health (NIH) and the Centers for Disease Control and Prevention, many of whom had already had abstracts peer reviewed and accepted. Attendees from other agencies and universities and HHS employees in Asia are not affected.

As of early June, more than 50 presentations from US government researchers have been canceled. Direct financial support from the US, previously the meeting's biggest contributor, has been cut to $\$ 250,000$ from $\$ 1.1$ million in 2002 . The European Union, Canada, Sweden and Thailand all contributed more than that amount, says conference director Mats Ahnlund.

The Bangkok conference is not the only one to have lost US government support. At the Global Health Council meeting in June, the organization's president Nils Daulaire blasted the HHS and other US agencies for cutting funds after " $\mathrm{a}$ small clique of right-wing extremists" objected to participants who don't oppose abortion.

HHS spokesman Bill Pierce says the travel restrictions stem from a new policy, decided last year. In order to spend tax dollars in a more "responsible way," the HHS now limits to 40 the number of employees who can travel to any conference abroad, he says, but the Bangkok contingent was extended to 50 because of the meeting's exceptional scale.

The decision to cut attendees was first relayed to NIH personnel in an e-mail dated 9 February, but made no mention of other international AIDS conferences, including an April meeting in Whistler, Canada. That meeting's list of attendees includes the names of 107 HHS employees.

But many AIDS researchers, including conference co-chair Joep Lange, say they doubt the cuts are driven by budget considerations. Instead, says Lange, president of the International AIDS Society, "religious fanatics" within the US administration are to blame.

Lange says it is "inconceivable" that a country spending \$15 billion on fighting AIDS would limit travel because of financial constraints. $\mathrm{He}$ adds that he has received no reply to a 3 May letter to HHS secretary Tommy Thompson, in which the society and the Thai government offered financial assistance to HHS researchers.

The administration may have been irked

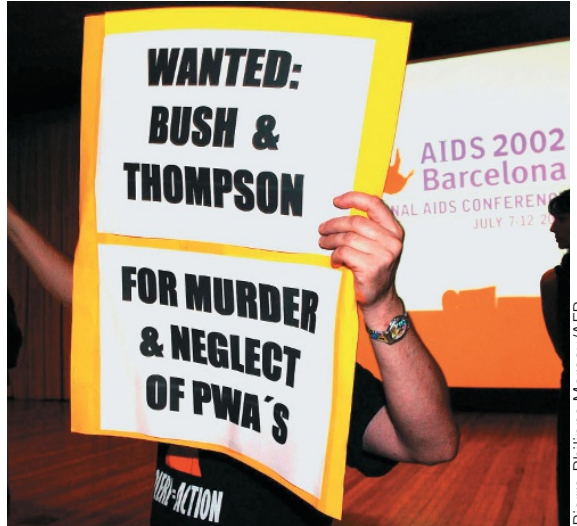

Protests at the last AIDS meeting may be the reason for a poorer US presence in Bangkok.

when they failed to land prominent spots for faith-based approaches in the meeting program, Lange suggests. For instance, he says, officials had suggested that the organizers invite Franklin Graham, son and successor of evangelist Billy Graham, as a keynote speaker-an idea Lange says he respectfully declined. "I did not think this speaker would have been representative for religions worldwide," he says.

Some in the administration are still upset over activists' heckling of Thompson in 2002. In an open letter to Lange in May, five Republican members of the House of Representatives complained about Thompson's "rude reception" in Barcelona and about "a seeming bias against the scientifically proven success of programs that promote [sexual] abstinence and faithfulness."

Pierce says suspicions that the administration's motives were political are off the mark. It is perfectly normal for the US government, as a principal conference sponsor, to suggest speakers, he adds. "Ultimately it's up to the organizers whom to invite," he says. "There is no policy of consequence."

Whatever the real reasons, the commotion over US attendance "has tainted the conference's overall message of cooperation and solidarity," says Mario Stevenson, a molecular biologist at the University of Massachusetts. "HHS may indeed be shifting money from travel to research-in principle, I'm all for that," he says. "I just hope that was their motive."

Peter Vermij, Amsterdam

\section{$\mathrm{NIH}$ mulls plan to lower cost of AIDS drugs}

Responding to controversy over the steep price hike of a popular AIDS drug, the US National Institutes of Health (NIH) is assessing whether an obscure law gives the agency the right to 'march in' and force the drug's patent holder to license its patent to generics manufacturers.

The US government and pharmaceutical industry face mounting global pressure to provide affordable AIDS drugs. The US has long insisted that its aid money fund expensive patented medications, but in a surprise policy shift in May, the government announced it would allow cheap generics that clear an expedited review process. Five companies also agreed last year to slash antiretroviral drug prices in 16 Caribbean and African countries. Jamaica in May became the first country to benefit from that deal.

Meanwhile, last year's $400 \%$ price increase for the eight-year-old drug Norvir, made by Illinois-based Abbott Laboratories, hit the NIH radar after letters poured in from activists, politicians and physician groups, says Mark Rohrbaugh, head of the NIH's technology transfer office. Norvir is a protease inhibitor that has become integral for boosting the activity of other AIDS drugs.

The NIH held a public forum on the issue when Essential Inventions, a Washington-based advocacy group, urged the NIH to use the 1980 Bayh-Dole Act to intervene against Abbott. At issue is a provision of the act that says the government can "march in" if governmentfunded innovations are not made "available to the public on reasonable terms.” The NIH gave Abbott nearly \$3.5 million for preclinical work on Norvir.

Rohrbaugh and other NIH officials plan to prepare recommendations on whether the agency should intervene on Bayh-Dole grounds, but Rohrbaugh declines to say when.

Abbott executives counter that the argument does not apply because Norvir is available in 60 countries. "There is no legal basis for march-in rights," says John Leonard, Abbott's vicepresident for development of global pharmaceutical research and development. Leonard says the price hike better reflects Norvir's real contribution to fighting AIDS. "[Essential Inventions] has tried to twist the Bayh-Dole Act's words into a vehicle to impose price controls," says Leonard, adding that, at \$8.57 per day, Norvir costs less than other AIDS drugs. Bristol-Myers Squibb's protease inhibitor Reyataz costs $\$ 22$ a day and GlaxoSmithKline's Lexiva is priced at \$32. Paroma Basu, New York 